\title{
Analysis of Combustion Rate of Various Carbon Materials for Iron Ore Sintering Process
}

\author{
Kenji MURAKAMI, ${ }^{1{ }^{*}}$ Katsuyasu SUGAWARA ${ }^{1)}$ and Takazo KAWAGUCHI') \\ 1) Department of Engineering in Applied Chemistry, Faculty of Engineering and Resource Science, Akita University, Akita, 010- \\ 8502 Japan. $\quad$ 2) Nippon Steel \& Sumitomo Metal Corporation, Kamisu, Ibaraki, 314-0255 Japan.
}

(Received on January 25, 2013; accepted on February 15, 2013)

\begin{abstract}
The aim of this study was to relate the combustion rate of solid fuel for iron ore sintering process to its physical and chemical properties. In this study, we used 23 carbon materials including cokes, anthracites, charcoals, and so on. The physical and chemical properties of the carbon materials such as proximate and ultimate analysis, specific surface area, particle density, and porosity were evaluated. The combustion rates of the carbon materials were measured using thermobalance and fixed-bed combustion reactor. In the low temperature region, the combustion rates depended on the types of the carbon materials. This would be because the carbon structure and the volatile matter content affected the combustion rates significantly. In the high temperature region, on the other hand, the combustion rates were almost the same regardless of the types of the carbon materials.
\end{abstract}

KEY WORDS: carbon material; combustion rate; physical and chemical property; activation energy.

\section{Introduction}

In general, cokes and anthracites are used as a solid fuel in the iron ore sintering process. However, the solid fuel for the iron ore sintering process must be reconsidered due to the sudden rise of the coke price, the unstable supply of the anthracites, and the global warming issue by $\mathrm{CO}_{2}$ emission. From this point of view, biomass is becoming an attractive alternative source to the traditional cokes and anthracites because the biomass is a carbon neutral and available in large amounts. ${ }^{1-4)}$ At present, however, we don't have any knowledge on the carbon material suitable for the alternative solid fuel. One of the best methods for the simulation of iron ore sintering process is a pot test, but it is inappropriate to the fundamental analysis of the combustion characteristics of the carbon materials. We can obtain the guideline for selecting the carbon material by knowing the combustion characteristics of the carbon material such as the combustion rate, the calorific value, the ignition temperature and so on. Among them, we paid attention to the combustion rate of the carbon material in this study. It is generally known that the combustion rate determining steps were divided into three zones by the temperature region. ${ }^{5-7)}$ In the low temperature region (Zone I), the reaction between carbon and oxygen on the surface of carbon material is controlled by chemical kinetics. In the middle temperature region (Zone II), the combustion rate is influenced by the pore diffusion as well as the chemical kinetics. And in the high temperature region (Zone III), the reaction is controlled

* Corresponding author: E-mail: murakami@ipc.akita-u.ac.jp DOI: http://dx.doi.org/10.2355/isijinternational.53.1580 by the transportation of the oxygen molecules through the external gas film around the solid particle.

Kucukbayrak et al. examined the relationship between the combustion reactivities of 25 lignite samples and their physical and chemical properties. ${ }^{8)}$ They concluded that an increase in the volatile matter content caused a decrease in the activation energy, the activation energy increased with increasing the total carbon or fixed carbon content, and the pore structure of the raw lignite affected the activation energy although the pore diameter and porosity of the lignite samples were progressively modified by continued combustion. They also studied that the effect of mineral matter on the combustion of lignite chars and concluded that the mineral species exert a strong catalytic effect on the combustion reactivity of the char samples. ${ }^{9}{ }^{9}$ Ma et al. reported that the char structure, including pore size distribution and porosity, played a key role in determining particle burnout times because the char conversion rate depended upon the accessibility of the internal surfaces under Zone II combustion condition. ${ }^{10)}$ Although it is considered that the combustion rate of the carbon material relates closely to its physical and chemical properties (the proximate and ultimate analyses, the porosity, the specific surface area, the density, and so on), the relationship has not been examined sufficiently. In this study, we aimed to clarify the relationship between the combustion rates of the carbon materials and their physical and chemical properties.

\section{Experimental}

\subsection{Carbon Materials}

We used 23 carbon materials shown in Table 1, which 
Table 1. Proximate and ultimate analyses of raw carbon materials.

\begin{tabular}{|c|c|c|c|c|c|c|c|c|c|c|}
\hline \multirow[b]{2}{*}{ Case } & \multirow[b]{2}{*}{ Sample } & \multicolumn{3}{|c|}{ Proximate analysis } & \multicolumn{5}{|c|}{ Ultimate analysis } & \multirow[b]{2}{*}{$\mathrm{H} / \mathrm{C}$} \\
\hline & & Ash & $\begin{array}{l}\text { V.M. } \\
\text { t } \% \text {, dr }\end{array}$ & $\begin{array}{l}\text { F.C. } \\
y\end{array}$ & $\mathrm{C}$ & $\begin{array}{l}\mathrm{H} \\
\mathrm{wt}^{\circ}\end{array}$ & $\begin{array}{l}\mathrm{N} \\
\%, \mathrm{~d}\end{array}$ & $\begin{array}{r}S \\
\text { a.f. }\end{array}$ & $\mathrm{O}^{\mathrm{diff}}$ & \\
\hline 1 & Coke 1 & 11.6 & 1.8 & 86.6 & 93.8 & $<0.1$ & 2.2 & 0.59 & 3.4 & 0.01 \\
\hline 2 & Coke 2 & 11.3 & 1.1 & 87.6 & 93.0 & $<0.1$ & 2.0 & 0.60 & 4.4 & 0.01 \\
\hline 3 & Coke 3 & 11.6 & 1.0 & 87.4 & 91.0 & 0.1 & 1.8 & 0.61 & 6.5 & 0.01 \\
\hline 5 & Coke 5 & 11.2 & 0.8 & 88.0 & 95.3 & $<0.1$ & 1.7 & 0.66 & 2.3 & 0.01 \\
\hline 6 & $\begin{array}{l}\text { Fine coke } \\
\text { powder } 1\end{array}$ & 9.4 & 1.0 & 89.6 & 90.4 & $<0.1$ & 1.3 & 0.62 & 7.7 & 0.01 \\
\hline 7 & $\begin{array}{l}\text { Fine coke } \\
\text { powder } 2\end{array}$ & 10.3 & 1.4 & 88.3 & 93.7 & 0.1 & 1.6 & 0.68 & 3.9 & 0.01 \\
\hline 8 & $\begin{array}{l}\text { Fine coke } \\
\text { powder } 3\end{array}$ & 10.5 & 4 & 85.4 & 90.9 & 0.4 & 1.5 & 0.53 & 6.7 & 0.05 \\
\hline 9 & Anthracite 1 & 10.5 & 6.0 & 83.5 & 92.6 & 3.7 & 1.9 & 0.41 & 1.4 & 0.48 \\
\hline 10 & Anthracite 2 & 6.5 & 6.5 & 87.0 & 89.8 & 3.5 & 1.8 & 0.49 & 4.4 & 0.47 \\
\hline 11 & Anthracite 3 & 8.5 & 11.2 & 80.3 & 81.9 & 4.3 & 1.6 & 0.44 & 11.8 & 0.63 \\
\hline 12 & Graphite 1 & 16.2 & 3.5 & 80.3 & 97.1 & 0.2 & 0.7 & 0.07 & 1.9 & 0.02 \\
\hline 13 & Graphite 2 & 0.3 & 1.0 & 98.7 & 98.5 & $<0.1$ & 0.7 & $<0.01$ & 0.8 & 0.01 \\
\hline 14 & Char & 0 & 34.6 & 63.4 & 74.0 & 4.7 & 0.6 & 0.06 & 20.6 & 0.76 \\
\hline 15 & Charcoal 2 & 1.6 & 32.4 & 66.0 & 66.4 & 3.7 & 0.7 & $<0.01$ & 29.2 & 0.67 \\
\hline 16 & Caking coal & 5.5 & 24.8 & 69.7 & 71.6 & 4.3 & 1.9 & 0.39 & 21.8 & 0.72 \\
\hline 17 & $\begin{array}{l}\text { Sligtly caking } \\
\text { coal }\end{array}$ & 6.4 & 31.1 & 62.5 & 79.3 & 4.5 & 2.1 & 0.46 & 13.6 & 0.68 \\
\hline 18 & $\begin{array}{l}\text { Subbituminous } \\
\text { coal }\end{array}$ & 1.1 & 46.6 & 52.3 & 72.4 & 4.9 & 1.3 & 0.12 & 21.3 & 0.81 \\
\hline 19 & Pitch 1 & 1.1 & 1.1 & 97.8 & 95.8 & $<0.1$ & 2.3 & 0.41 & 1.5 & 0.01 \\
\hline 20 & Pitch 2 & 0.2 & 36.3 & 63.5 & 72.3 & 5.0 & 1.5 & 5.77 & 15.4 & 0.83 \\
\hline 26 & Charcoal 3 & 3.6 & 4.0 & 92.4 & 97.7 & 0.7 & 0.7 & 0.09 & 0.8 & 0.09 \\
\hline 27 & Charcoal 4 & 3.1 & 5.2 & 91.7 & 95.3 & 1.2 & 0.6 & 0.04 & 2.9 & 0.15 \\
\hline 28 & Biomass char 1 & 8.7 & 3.1 & 88.1 & 95.4 & 0.7 & 0.8 & 0.09 & 3.0 & 0.09 \\
\hline 29 & Biomass char 2 & 6.1 & 25.1 & 68.8 & 78.8 & 2.5 & 1.2 & 0.03 & 17.5 & 0.38 \\
\hline
\end{tabular}

were provided from Sumitomo Metal Industries, Ltd. These carbon materials were sieved between 150 and $250 \mu \mathrm{m}$, stored in a desiccator, and dried at $110^{\circ} \mathrm{C}$ for $1 \mathrm{~h}$ prior to use. Hereafter, these samples are designated as raw carbon materials. Further, the carbon materials with large amounts of volatile matter were heated at $925^{\circ} \mathrm{C}$ for $7 \mathrm{~min}$ to remove the volatile matter (Table 2). Hereafter, these carbon materials are designated as devolatilized carbon materials.

\subsection{Proximate and Ultimate Analyses}

The proximate analysis of the raw and devolatilized carbon materials was performed on the basis of JIS M 8812 . The ash content (wt \%) was calculated from the amount of residue when $1 \mathrm{~g}$ of the carbon material was calcined at $815^{\circ} \mathrm{C}$ for $1 \mathrm{~h}$ in the air. The volatile matter content (wt\%) was derived from the ratio of the decreased amount of weight after heating at $925^{\circ} \mathrm{C}$ for $7 \mathrm{~min}$ to the unheated sample weight $(1 \mathrm{~g})$. The fixed carbon content ( $\mathrm{wt} \%)$ was calculated by subtracting the ash content (wt\%) and volatile matter content (wt\%) from $100 \mathrm{wt} \%$. These analytical values in Tables 1 and 2 are shown on the dry basis (dry).

Carbon, hydrogen, nitrogen, and sulfur contents ( $\mathrm{wt} \%$ ) in
Table 2. Proximate and ultimate analyses of devolatilized carbon materials.

\begin{tabular}{|c|c|c|c|c|c|c|c|c|c|}
\hline \multirow[b]{2}{*}{ Case } & \multirow[b]{2}{*}{ Sample } & \multicolumn{3}{|c|}{ Proximate analysis } & \multicolumn{4}{|c|}{ Ultimate analysis } & \multirow[b]{2}{*}{$\mathrm{H} / \mathrm{C}$} \\
\hline & & Ash & $\begin{array}{l}\text { V.M. } \\
\mathrm{Nt}^{\mathrm{O}} \% \text {, dr }\end{array}$ & $\begin{array}{l}\text { F.C. } \\
\mathrm{y}\end{array}$ & \multicolumn{3}{|c|}{ wt $\%$, d.a.f. } & $\mathrm{O}^{\text {diff }}$ & \\
\hline 14 & Charcoal 1 & 3.1 & 1.8 & 95.1 & 95.2 & 0.40 .6 & 0.07 & 3.7 & 0.05 \\
\hline 15 & Charcoal 2 & 2.4 & 1.6 & 96.0 & 98.3 & 0.40 .5 & 0.06 & 0.7 & 0.05 \\
\hline 16 & Caking coal & 7.3 & 1.5 & 91.2 & 94.7 & 0.62 .3 & 0.39 & 2.0 & 0.08 \\
\hline 17 & Sligtly caking coal & 9.3 & 1.1 & 89.6 & 94.9 & 0.62 .4 & 0.31 & 1.8 & 0.08 \\
\hline 18 & Subbituminous coal & 2.1 & 2.0 & 95.9 & 93.9 & 0.61 .2 & 0.10 & 4.2 & 0.08 \\
\hline 26 & Charcoal 3 & 3.8 & 1.8 & 94.4 & 96.9 & 0.30 .8 & 0.07 & 1.9 & 0.04 \\
\hline 27 & Charcoal 4 & 3.3 & 2.1 & 94.6 & 93.1 & 0.40 .8 & 0.04 & 5.7 & 0.05 \\
\hline 28 & Biomass char 1 & 9.0 & 1.9 & 89.1 & 92.9 & 0.40 .7 & 0.02 & 6.0 & 0.05 \\
\hline 29 & Biomass char 2 & 8.1 & 2.5 & 89.4 & 93.8 & 0.60 .8 & 0.02 & 4.8 & 0.08 \\
\hline
\end{tabular}

the raw and devolatilized carbon materials were measured using a Yanaco HCN corder MT-700 HCN instrument and a Horiba Carbon/Sulfur Analyzer EMIA-220V instrument. These analytical values in Tables 1 and 2 are shown on the dry ash free basis (d.a.f.).

\subsection{Characterization of Carbon Materials}

True density $\left(\rho_{\mathrm{t}}\left[\mathrm{g} / \mathrm{cm}^{3}\right]\right)$ and particle density $\left(\rho_{\mathrm{p}}\left[\mathrm{g} / \mathrm{cm}^{3}\right]\right)$ were defined as the densities of the carbon materials with the particle diameter under $40 \mu \mathrm{m}$ and $150-250 \mu \mathrm{m}$, respectively. The sample dried at $150^{\circ} \mathrm{C}$ for $1 \mathrm{~h}(M[\mathrm{~g}])$ was placed in a pycnometer with deionized water. The pycnometer was degassed by an aspirator until the deionized water penetrated into the pore of the carbon materials sufficiently. Then, the pycnometer filled with deionized water was weighed $(N$ $[\mathrm{g}])$. The true density and particle density of the carbon material were calculated using the weight of the pycnometer filled with only deionized water $(P[\mathrm{~g}])$,

$$
\rho_{\mathrm{t}} \text { and } \rho_{\mathrm{p}}=\frac{M}{(M-N+P) / \rho},
$$

where $\rho\left[\mathrm{g} / \mathrm{cm}^{3}\right]$ is the density of deionized water at the measurement temperature.

Nitrogen adsorption measurements were performed at 77 K on a Quantachrome NOVA $1200 / \mathrm{S}$ instrument. The BET specific surface area $\left(S\left[\mathrm{~m}^{2} / \mathrm{g}\right]\right)$ was calculated using adsorption branch in the relative pressure ranging from 0.1 to 0.3 . The apparent particle density $\left(\rho_{\mathrm{a}}\left[\mathrm{g} / \mathrm{cm}^{3}\right]\right)$ was calculated using the particle density described above and the open pore volume $\left(V\left[\mathrm{~cm}^{3} / \mathrm{g}\right]\right)$ derived from the BJH analysis of the nitrogen adsorption isotherm,

$$
\rho_{\mathrm{a}}=\frac{1}{1 / \rho_{\mathrm{p}}+V} .
$$

The porosity $(\varepsilon)$ was calculated from the following equation using the true density and the apparent particle density,

$$
\varepsilon=1-\frac{\rho_{\mathrm{a}}}{\rho_{\mathrm{t}}} .
$$

\subsection{Combustion of Carbon Materials}

\subsubsection{Combustion in Zone I}

The combustion rates of the raw and devolatilized carbon 
materials were measured using a Bruker TG-DTA 2000 SA instrument. The carbon materials $(20 \mathrm{mg})$ were heated from room temperature to $1000^{\circ} \mathrm{C}$ at the heating rate of $10^{\circ} \mathrm{C} / \mathrm{min}$ under air flow $(200 \mathrm{~mL} / \mathrm{min})$. The analytical method reported previously ${ }^{11-14)}$ was applied to the determination of the combustion rate. As an example of analysis, the thermogravimetric curve of Coke 3 is shown in Fig. 1(a), where $X$ is the weight conversion on the d.a.f. basis. The white circles in this figure indicate the data points at $X=0.05,0.1,0.15$, and 0.2. The combustion rate of the carbon materials at $X$ $\left(R_{X}[1 / \mathrm{s}]\right)$ was calculated by substituting the differential value shown in Fig. 1(b) to the following equation,

$$
R_{X}=\frac{1}{1-X} \frac{d X}{d t} .
$$

As a result, the Arrhenius plot was obtained by plotting the combustion rate against the reciprocal of temperature.

\subsubsection{Combustion in Zone II and Zone III}

The combustion rates in Zone II and Zone III were measured using a fixed-bed combustion equipment shown in Fig. 2. In this equipment, two electric furnaces were arranged side by side and the temperature could be con-
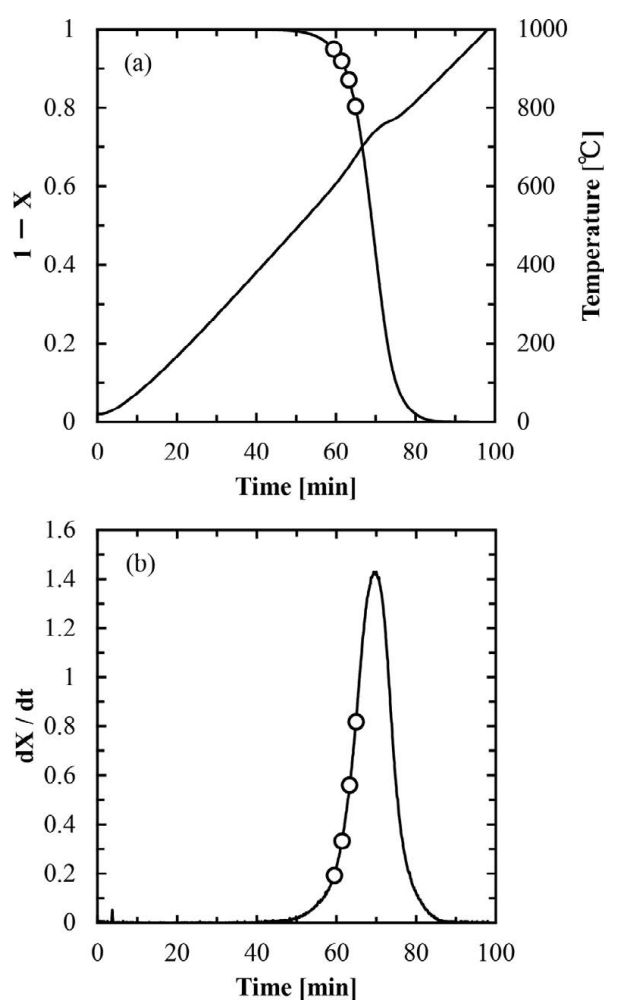

Fig. 1. (a) Thermogravimetric curve of Coke 3. (b) Differential curve of thermogravimetry of Coke 3 .

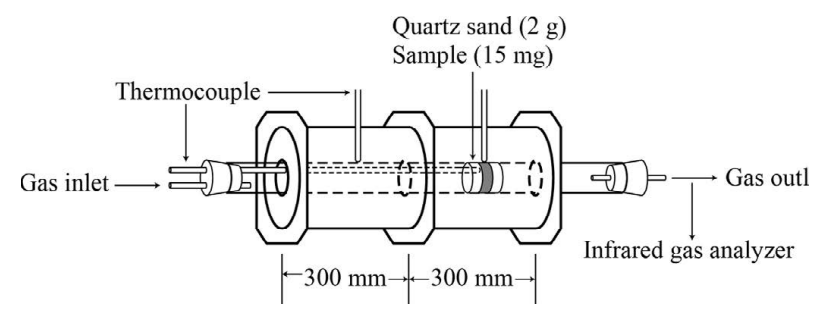

Fig. 2. Schematic illustration of fixed-bed combustion equipment. trolled independently. The furnace at the gas inlet side was placed to pre-heat the inlet gas and the other was placed to combust the carbon materials. The mixture of the carbon material $(15 \mathrm{mg}$ ) and quartz sand (about $2 \mathrm{~g}$ ) was used as the sample for the combustion experiment. The mixed sample was set in a quartz glass tube, and then the nitrogen was introduced into the reactor. The sample was heated to the desired temperature between 450 and $950^{\circ} \mathrm{C}$ and kept at the temperature. After $5 \mathrm{~min}$, the flow gas was switched to the air flow (3.0 L-ntp/min). The amounts of $\mathrm{CO}, \mathrm{CO}_{2}, \mathrm{O}_{2}$ in the produced gas were analyzed using Shimadzu portable gas analyzer CGT-7000. After the $\mathrm{CO}$ and $\mathrm{CO}_{2}$ finished being evolved, the sample was cooled to the room temperature. As an example of analysis, $\mathrm{CO}$ and $\mathrm{CO}_{2}$ evolution profiles during combustion of Coke 3 at $700^{\circ} \mathrm{C}$ are shown in Fig. 3(a). Since the sum of the $\mathrm{CO}$ and $\mathrm{CO}_{2}$ evolution rates provides the carbon combustion rate, the integration of the carbon combustion rate gives the change in carbon conversion with combustion time as shown in Fig. 3(b). From these figures, the carbon combustion rate at $X=0.15$ (white circle) was obtained similar to the case of Zone I.

\subsection{Analysis of Combustion Rate}

In this study, the analysis of combustion rate was carried out according to the equations and method proposed by Lin et al. ${ }^{5)}$ The combustion rate per unit volume of the carbon material in Zone $\mathrm{I}\left(R_{\mathrm{I}}\left[\mathrm{mol} /\left(\mathrm{m}^{3} \cdot \mathrm{s}\right)\right]\right)$ is given by

$$
R_{\mathrm{I}}=k_{v} C_{\infty}=A \exp \left(-\frac{E}{R_{\mathrm{g}} T}\right) \times\left(\frac{T_{0}}{T}\right) C_{0},
$$
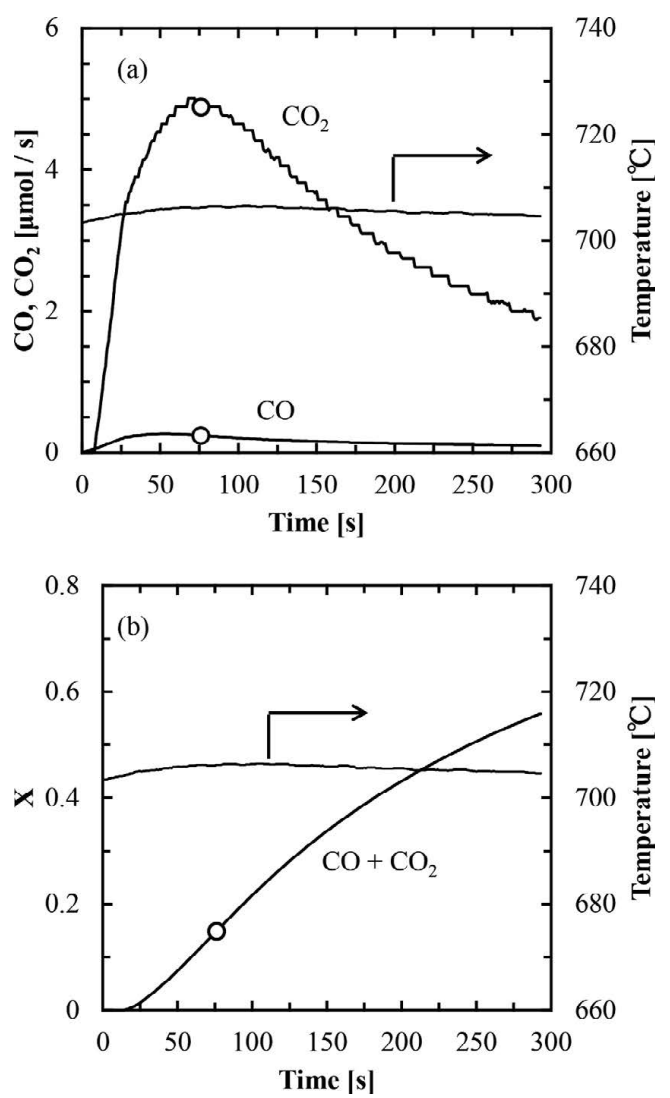

Fig. 3. (a) $\mathrm{CO}$ and $\mathrm{CO}_{2}$ evolution profiles during combustion of Coke 3 at $700^{\circ} \mathrm{C}$. (b) Carbon conversion for combustion of Coke 3 at $700^{\circ} \mathrm{C}$. 
where $k_{v}[1 / \mathrm{s}]$ is the intrinsic rate constant, $C_{\infty}\left[\mathrm{mol} / \mathrm{m}^{3}\right]$ is the oxygen concentration in the bulk gas at the operating temperature ( $T[\mathrm{~K}]), A[1 / \mathrm{s}]$ is the frequency factor, $E[\mathrm{~J} / \mathrm{mol}]$ is the activation energy, $R_{\mathrm{g}}[\mathrm{J} /(\mathrm{K} \cdot \mathrm{mol})]$ is the gas constant, and $C_{0}\left[\mathrm{~mol} / \mathrm{m}^{3}\right]$ is the oxygen gas concentration in the bulk gas at $T_{0}=273 \mathrm{~K}$.

The combustion rate per unit external surface area of the carbon material in Zone II $\left(R_{\mathrm{II}}\left[\mathrm{mol} /\left(\mathrm{m}^{2} \cdot \mathrm{s}\right)\right]\right)$ is given by

$$
R_{\mathrm{II}}=k_{s} C_{\infty}=k_{v}^{0.5} D_{e}^{0.5}\left(\frac{1}{\tanh \xi}-\frac{1}{\xi}\right) C_{\infty},
$$

where $k_{s}[\mathrm{~m} / \mathrm{s}]$ is the apparent combustion rate constant in Zone II, and $D_{e}\left[\mathrm{~m}^{2} / \mathrm{s}\right]$ is the effective diffusivity for internal diffusion. Thiele modulus for a sphere $(\xi[-])$ is defined by

$$
\xi=r_{\mathrm{p}} \sqrt{k_{v} / D_{e}}
$$

where $r_{\mathrm{p}}[\mathrm{m}]$ is the particle radius. The effective diffusivity for internal diffusion is defined by

$$
D_{e}=\varepsilon^{2}\left(\frac{T}{T_{0}}\right)^{1.5} D_{0}
$$

where $\varepsilon[-]$ is the porosity of the carbon material and $D_{0}$ $\left[\mathrm{m}^{2} / \mathrm{s}\right]$ is the molecular diffusivity at $T_{0}$. The Eq. (6) is reduced to the Eq. (5), when the $R_{\mathrm{II}}$ is multiplied by the ratio of a particle surface area to a particle volume, $S_{\mathrm{p}} / V_{\mathrm{p}}\left(=3 / r_{\mathrm{p}}\right.$ for a spherical particle), and the Thiele modulus is sufficiently small. Thus, we used the Eq. (6) as the expression of the combustion rate in the Zones I and II, hereafter.

In the Zone III, the combustion rate is limited by the mass transfer rate of oxygen through the external gas film around a particle. The combustion rate per unit external surface area of the carbon material $\left(R_{\mathrm{III}}\left[\mathrm{mol} /\left(\mathrm{m}^{2} \cdot \mathrm{s}\right)\right]\right)$ is given by

$$
R_{\mathrm{III}}=k_{d} C_{\infty}=\frac{S h}{d_{\mathrm{p}}} D_{\mathrm{g}} C_{\infty}
$$

where $k_{d}[\mathrm{~m} / \mathrm{s}]$ is the mass transfer coefficient for external diffusion, $S h[-]$ is the Sherwood number for a sphere, $d_{\mathrm{p}}$ [m] is the particle diameter, and $D_{\mathrm{g}}\left[\mathrm{m}^{2} / \mathrm{s}\right]$ is the molecular diffusivity. In this study, the Ranz-Marshall equation concerning a single spherical particle was used as the Sherwood number,

$$
S h=2.0+0.60 R e^{1 / 2} S c^{1 / 3}=2.0+0.60\left(\frac{d_{\mathrm{p}} u_{\mathrm{g}} \rho_{\mathrm{g}}}{\mu_{\mathrm{g}}}\right)^{1 / 2}\left(\frac{\mu_{\mathrm{g}}}{\rho_{\mathrm{g}} D_{\mathrm{g}}}\right)^{1 / 3},
$$

where $R e$ [-] is the particle Reynolds number, $S c$ [-] is the Schmidt number, $u_{\mathrm{g}}[\mathrm{m} / \mathrm{s}]$ is the interstitial gas velocity pass through particles, $\rho_{\mathrm{g}}\left[\mathrm{kg} / \mathrm{m}^{3}\right]$ is the density of gas, and $\mu_{\mathrm{g}}$ $[\mathrm{kg} /(\mathrm{m} \cdot \mathrm{s})]$ is the viscosity of gas.

The equation of overall combustion rate $\left(R_{\mathrm{I}-\mathrm{II}-\mathrm{III}}[\mathrm{mol} /\right.$ $\left.\left.\left(\mathrm{m}^{2} \cdot \mathrm{s}\right)\right]\right)$ is obtained by the combination of $R_{\mathrm{II}}$ and $R_{\mathrm{III}}$ as shown in the following equation,

$$
R_{\mathrm{I}-\mathrm{II}-\mathrm{III}}=\frac{1}{1 / R_{\mathrm{II}}+1 / R_{\mathrm{III}}}=\frac{C_{\infty}}{1 / k_{s}+1 / k_{d}} \ldots \ldots \ldots \ldots
$$

\section{Results and Discussion}

\subsection{Physical and Chemical Properties of Carbon Mate- rials}

The proximate and ultimate analyses of raw carbon materi- als were summarized in Table 1. A small amount of volatile matter $(<4.1 \mathrm{wt} \%)$ and a large amount of carbon $(>90.4 \mathrm{wt} \%)$ were characteristic of the cokes and fine coke powders. Moreover, the ash contents in these carbon materials were relatively high $(>9.4 \mathrm{wt} \%)$. The analytical values of the anthracites were similar to those of the cokes and fine coke powders, except that the anthracites had a slightly larger amount of volatile matter. In the case of other carbon materials, the ash contents extended over a wide range from $0.2 \mathrm{wt} \%$ (Pitch 2) to $16.2 \mathrm{wt} \%$ (Graphite 1). It is important to note the difference in volatile matter contents among the carbon materials, that is, there are some carbon materials with large amounts of volatile matter (>24.8 wt\%) such as Charcoal 1, Charcoal 2, Caking coal, Slightly caking coal, Subbituminous coal, Pitch 2, and Biomass char 2. On the contrary, the carbon contents in these carbon materials were very low $(<66.4 \mathrm{wt} \%)$. The $\mathrm{H} / \mathrm{C}$ atomic ratios of the cokes and fine coke powders shown in Table 1 were remarkably low $(<0.05)$ compared with those of the carbon materials with large amounts of volatile matter such as Subbituminous coal (0.81) and Pitch 2 (0.83). This indicates that the cokes and fine coke powders are relatively rich in aromatic carbons.

The proximate and ultimate analyses of the devolatilized carbon materials are summarized in Table 2. The analytical values of the devolatilized carbon materials were close to those of the cokes and fine coke powders. The amount of volatile matter in the devolatilized carbon materials decreased significantly to $1.1-2.5 \mathrm{wt} \%$, while the carbon contents increased to $92.9-98.3 \mathrm{wt} \%$. Further, the removal of the volatile matter from the carbon materials caused the decrease in the $\mathrm{H} / \mathrm{C}$ atomic ratios to $0.04-0.08$. In this way, even in the case of the carbon materials with large amounts of volatile matter, the proximate and ultimate analyses resembled to the other carbon materials with small amounts of volatile matter by removing the volatile matter.

The specific surface areas of the raw and devolatilized carbon materials are given in Table 3. The specific surface areas of cokes and anthracites were $20-50 \mathrm{~m}^{2} / \mathrm{g}$, which were significantly smaller those of Charcoal $4\left(210 \mathrm{~m}^{2} / \mathrm{g}\right)$ and Biomass char $1\left(160 \mathrm{~m}^{2} / \mathrm{g}\right)$. For the carbon materials with large amounts of volatile matter, the specific surface areas of carbon materials increased by removing the volatile matter compared to those of the corresponding raw carbon materials. This is considered that new pores are formed in the carbon materials during devolatilization.

Table 4 shows the particle densities of the raw carbon materials. The particle density was widely distributed from $1.55 \mathrm{~g} / \mathrm{cm}^{3}$ for Anthracite 1 to $2.24 \mathrm{~g} / \mathrm{cm}^{3}$ for Graphite 1 . In addition, as for Coke 3 and Charcoal 3 , the porosity was calculated by measuring the true density and the pore volume. In the case of Coke 3 , the porosity was 0.42 because the true density and the pore volume were $2.00 \mathrm{~g} / \mathrm{cm}^{3}$ and $0.34 \mathrm{~cm}^{3} / \mathrm{g}$, respectively. On the other hand, the porosity of Charcoal 3 was calculated at 0.55 from the values of true density $\left(1.83 \mathrm{~g} / \mathrm{cm}^{3}\right)$ and pore volume $\left(0.67 \mathrm{~cm}^{3} / \mathrm{g}\right)$. Kulaots et al. reported that the porosity of the carbon materials increased with increasing the burn-off time. ${ }^{15,16)}$ Thus, the porosities of Coke 3 and Charcoal 3 after combustion at $X=0.15$ were evaluated because we measured the initial combustion rate $(X=0.15)$ of the carbon materials described below. As a 
Table 3. Specific surface area $\left(\mathrm{m}^{2} / \mathrm{g}\right)$ of various carbon materials.

\begin{tabular}{cccc}
\hline Case & Sample & Raw $^{\mathrm{a})}$ & Devolatilized $^{\mathrm{b})}$ \\
\hline 3 & Coke 3 & 20 & - \\
5 & Coke 5 & 40 & - \\
6 & Fine coke powder 1 & 50 & - \\
7 & Fine coke powder 2 & 20 & - \\
8 & Fine coke powder 3 & 20 & - \\
9 & Anthracite 1 & 30 & - \\
11 & Anthracite 3 & 20 & - \\
12 & Graphite 1 & 10 & - \\
13 & Graphite 2 & 30 & - \\
14 & Charcoal 1 & 60 & 100 \\
15 & Charcoal 2 & 50 & 160 \\
16 & Caking coal & - & 50 \\
17 & Slightly caking coal & - & 30 \\
18 & Subbituminous coal & 30 & 110 \\
19 & Pitch 1 & $<5$ & - \\
26 & Charcoal 3 & 40 & 200 \\
27 & Charcoal 4 & 210 & 240 \\
28 & Biomass char 1 & 160 & 240 \\
29 & Biomass char 2 & - & 230 \\
\hline
\end{tabular}

a) Raw carbon materials

b) Devolatilized carbon materials

Table 4. Particle density $\left(\mathrm{g} / \mathrm{cm}^{3}\right)$ of raw carbon materials.

\begin{tabular}{ccc}
\hline Case & Sample & $\rho_{\mathrm{p}}$ \\
\hline 3 & Coke 3 & 1.92 \\
9 & Anthracite 1 & 1.55 \\
12 & Graphite 1 & 2.24 \\
13 & Graphite 2 & 2.16 \\
19 & Pitch 1 & 1.99 \\
26 & Charcoal 3 & 1.82 \\
27 & Charcoal 4 & 1.69 \\
\hline
\end{tabular}

result, the porosities of Coke 3 and Charcoal 3 increased to 0.46 and 0.73 , respectively.

\subsection{Combustion Rate of Carbon Materials}

Figure 4 shows the Arrhenius plots for the combustion of the raw carbon materials derived from the thermogravimetry. It is found that the combustion temperature of cokes and fine coke powders at $X=0.05-0.20$ was between 600 and $700^{\circ} \mathrm{C}$, which was higher than that of anthracites at $X=$ $0.05-0.20$ by about $100^{\circ} \mathrm{C}$. By fitting the Eq. (5) to the results in Fig. 4, the activation energy and the frequency factor can be obtained. Table 5 summarizes the activation energies for combustion of the raw carbon materials. The activation energies for cokes and fine coke powders were $120-160 \mathrm{~kJ} / \mathrm{mol}$, which were smaller than those for anthracites $(160-190 \mathrm{~kJ} / \mathrm{mol})$. On the other hand, the activation energies for the combustion of graphites were $220-230 \mathrm{~kJ} / \mathrm{mol}$, indicating that the graphites were hard to combust. For the carbon materials with large amounts of volatile matter, the activation energies distributed over the wide range between 70
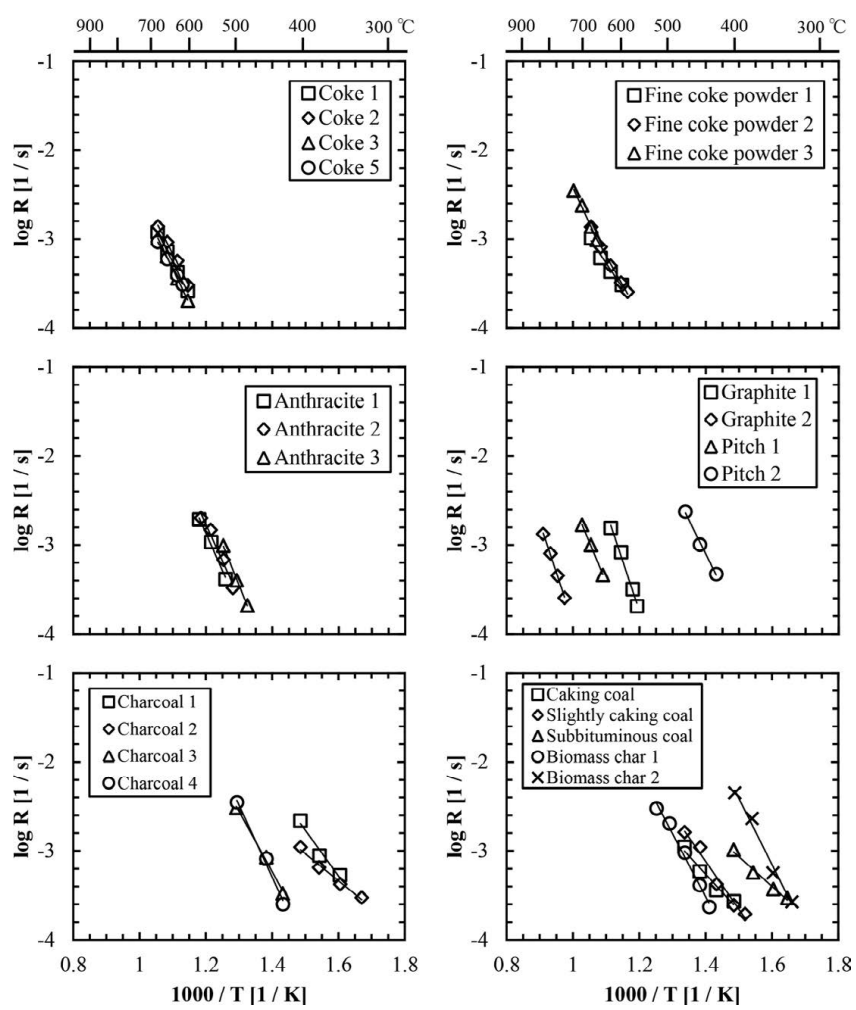

Fig. 4. Arrhenius plots for combustion of raw carbon materials.

Table 5. Activation energy and frequency factor of raw carbon materials (Raw) and devolatilized carbon materials (Devolatilized).

\begin{tabular}{|c|c|c|c|c|c|}
\hline \multirow{2}{*}{ Case } & \multirow{2}{*}{ Sample } & \multicolumn{2}{|c|}{ Raw } & \multicolumn{2}{|c|}{ Devolatilized } \\
\hline & & $\mathrm{E}[\mathrm{kJ} / \mathrm{mol}]$ & $\log A$ & $\mathrm{E}[\mathrm{kJ} / \mathrm{mol}]$ & $\log A$ \\
\hline 1 & Coke 1 & 140 & 9.7 & - & - \\
\hline 2 & Coke 2 & 150 & 10.1 & - & - \\
\hline 3 & Coke 3 & 150 & 10.1 & - & - \\
\hline 5 & Coke 5 & 130 & 8.9 & - & - \\
\hline 6 & Fine coke powder 1 & 120 & 8.1 & - & - \\
\hline 7 & Fine coke powder 2 & 130 & 8.7 & - & - \\
\hline 8 & Fine coke powder 3 & 160 & 10.7 & - & - \\
\hline 9 & Anthracite 1 & 170 & 12.7 & - & - \\
\hline 10 & Anthracite 2 & 160 & 12.2 & - & - \\
\hline 11 & Anthracite 3 & 190 & 14.0 & - & - \\
\hline 12 & Graphite 1 & 220 & 14.8 & - & - \\
\hline 13 & Graphite 2 & 230 & 12.7 & - & - \\
\hline 14 & Charcoal 1 & 110 & 10.1 & 140 & 11.7 \\
\hline 15 & Charcoal 2 & 70 & 6.8 & 140 & 11.4 \\
\hline 16 & Caking coal & 90 & 7.5 & 180 & 12.4 \\
\hline 17 & Slightly caking coal & 110 & 9.2 & 140 & 10.7 \\
\hline 18 & Subbituminous coal & 80 & 7.5 & 140 & 10.9 \\
\hline 19 & Pitch 1 & 190 & 12.2 & - & - \\
\hline 20 & Pitch 2 & 150 & 12.7 & 140 & 10.4 \\
\hline 26 & Charcoal 3 & 140 & 11.5 & 160 & 12.7 \\
\hline 27 & Charcoal 4 & 160 & 13.2 & 160 & 12.3 \\
\hline 28 & Biomass char 1 & 140 & 11.5 & 150 & 12.1 \\
\hline 29 & Biomass char 2 & 150 & 13.8 & 150 & 12.1 \\
\hline
\end{tabular}


and $160 \mathrm{~kJ} / \mathrm{mol}$. Figure 5 shows the Arrhenius plots for the combustion of the devolatilized carbon materials. The combustion temperatures of the devolatilized carbon materials at $X=0.05-0.2$ shifted to the higher side by $50-200^{\circ} \mathrm{C}$ compared to those for the corresponding raw carbon materials, and particularly Caking coal and Slightly caking coal burned in the same temperature region as the case of cokes and anthracites. However, the combustion temperature of the carbon materials prepared from biomass such as charcoals and biomass chars were low compared to those for the cokes, although the volatile matter was removed from the carbon materials. The activation energies for the combustion
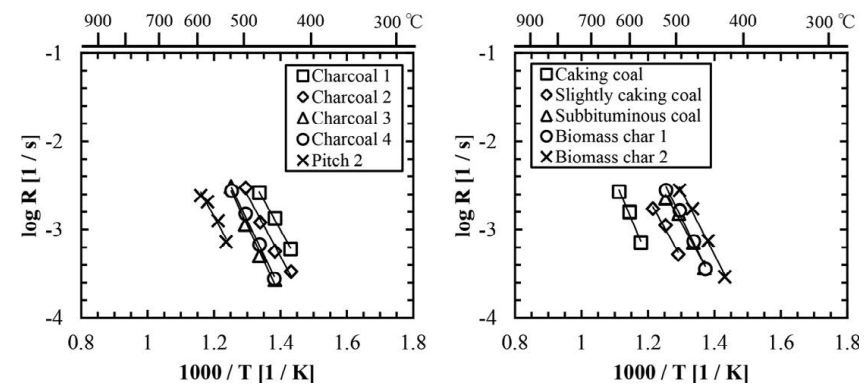

Fig. 5. Arrhenius plots for combustion of devolatilized carbon materials.
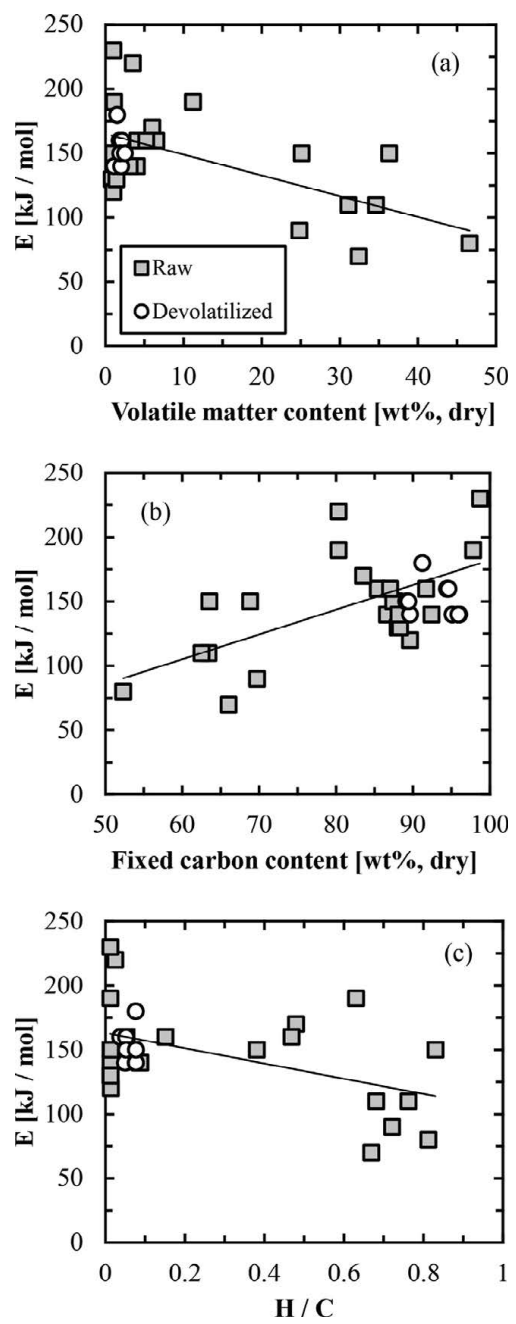

Fig. 6. Relationship between the activation energy and (a) volatile matter content, (b) fixed carbon content, and (c) H/C atomic ratio. of the devolatilized carbon materials were $140-180 \mathrm{~kJ} / \mathrm{mol}$, which were almost the same as those of cokes. Above results indicate that the volatile matter promotes the combustion of the fixed carbon.

In order to investigate how the proximate and ultimate analyses of the carbon materials influence its activation energy for the combustion, the variations of activation energy with the volatile matter content, the fixed carbon content, and the $\mathrm{H} / \mathrm{C}$ atomic ratio are shown in Fig. 6. It was observed in Fig. 6(a) that an increase in the volatile matter content of the carbon materials caused, as a general tendency, a decrease in the activation energy. From Fig. 6(b), it was found that activation energy increased with increasing the fixed carbon content. Also, it was seen in Fig. 6(c) that the activation energy had a tendency of decreasing with increasing the $\mathrm{H} / \mathrm{C}$ atomic ratio, indicating that the activation energies decreased with increasing the ratio of aliphatic carbon to total carbon. Similarly, Fig. 7 shows the relationship between the frequency factor and the proximate and ultimate analyses. As a general tendency, the increases in the volatile matter content and the $\mathrm{H} / \mathrm{C}$ atomic ratio and the decrease in the fixed carbon content resulted in the decrease in the frequency factor. From these results, it was suggested that we could expect the activation energy and frequency factor to some degree by measuring the proximate and ulti-
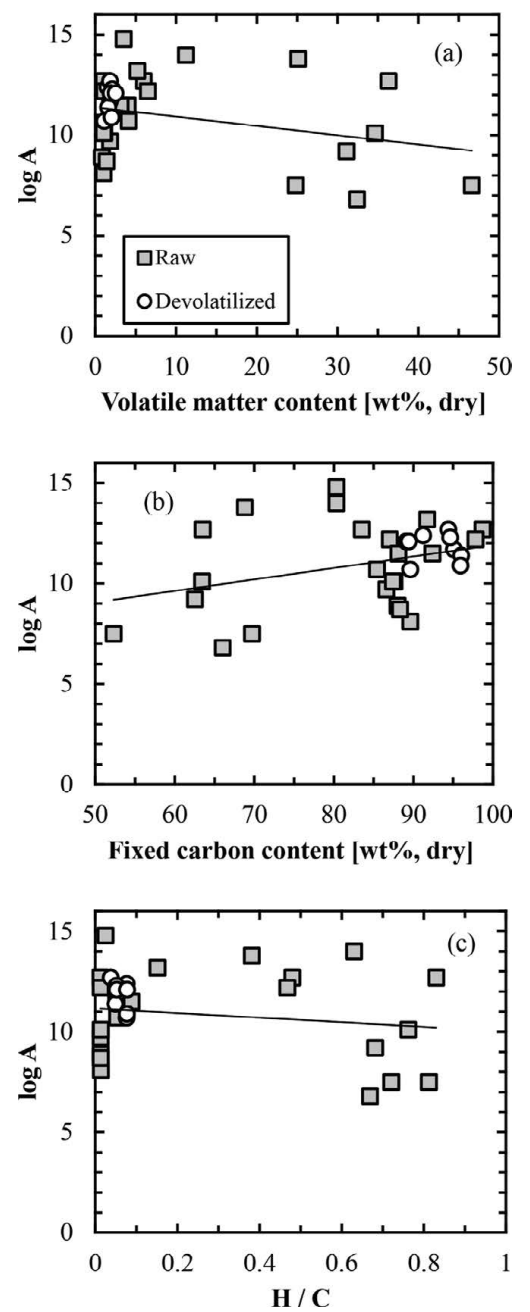

Fig. 7. Relationship between the frequency factor and (a) volatile matter content, (b) fixed carbon content, and (c) H/C atomic ratio. 
mate analyses.

Figure 8 shows the Arrhenius plots for the combustion obtained by using the fixed-bed reactor. It was observed that the combustion rates depended on the types of the carbon materials below about $850^{\circ} \mathrm{C}$. Above this temperature, on the other hand, the combustion rates became almost the same regardless of the carbon materials and the activation energies calculated from the slopes were $10-50 \mathrm{~kJ} / \mathrm{mol}$ in all the carbon samples except for Graphite 2 (Table 6).
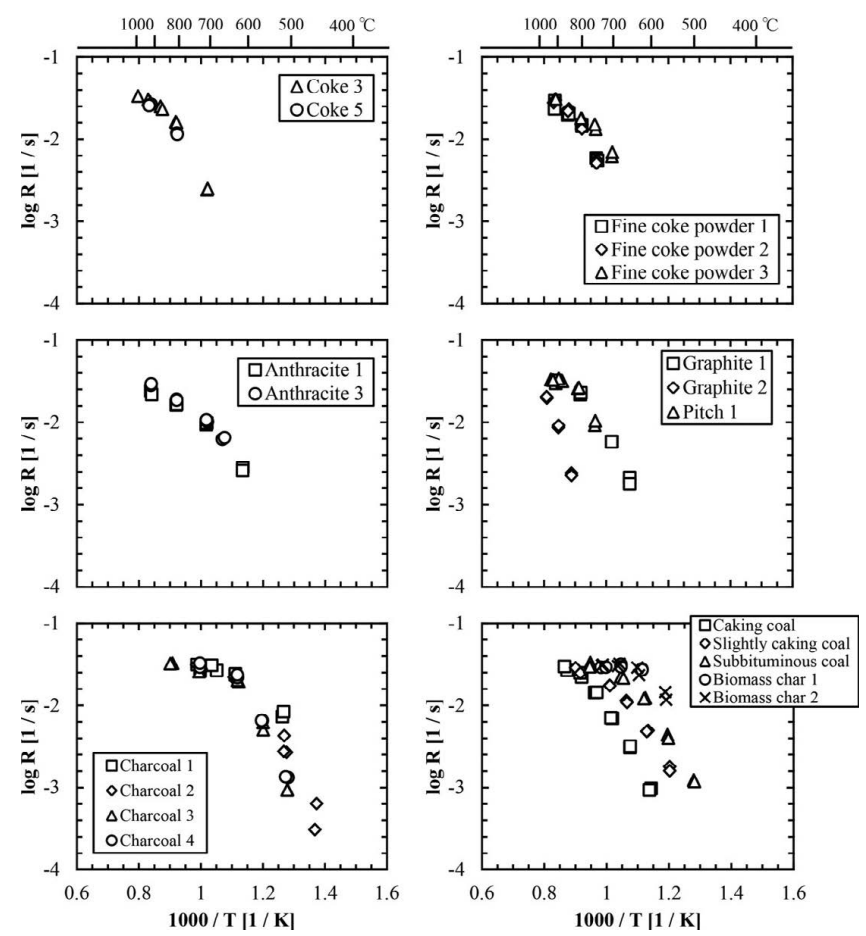

Fig. 8. Arrhenius plots for combustion of carbon materials obtained using the fixed-bed reactor.

Table 6. Apparent activation energy for combustion of carbon materials in the high temperature range.

\begin{tabular}{|c|c|c|}
\hline Case & Sample & $\mathrm{E}[\mathrm{kJ} / \mathrm{mol}]$ \\
\hline 3 & Coke 3 & 40 \\
\hline 5 & Coke 5 & 50 \\
\hline 6 & Fine coke powder 1 & 50 \\
\hline 7 & Fine coke powder 2 & 40 \\
\hline 8 & Fine coke powder 3 & 50 \\
\hline 9 & Anthracite 1 & 40 \\
\hline 11 & Anthracite 3 & 40 \\
\hline 12 & Graphite 1 & 30 \\
\hline 13 & Graphite 2 & 220 \\
\hline 14 & Charcoal 1 & 10 \\
\hline 15 & Charcoal 2 & 20 \\
\hline 16 & Caking coal & 30 \\
\hline 17 & Slightly caking coal & 40 \\
\hline 18 & Subbituminous coal & 40 \\
\hline 19 & Pitch 1 & 20 \\
\hline 26 & Charcoal 3 & 20 \\
\hline 27 & Charcoal 4 & 20 \\
\hline 28 & Biomass char 1 & 10 \\
\hline 29 & Biomass char 2 & 10 \\
\hline
\end{tabular}

\subsection{Analysis of Combustion Rate}

There is a following relationship between the experimental value $\left(R_{X=0.15}[1 / \mathrm{s}]\right)$, and $R_{\mathrm{I}-\mathrm{II}-\mathrm{III}}\left[\mathrm{mol} /\left(\mathrm{m}^{2} \cdot \mathrm{s}\right)\right]$,

$$
R_{X=0.15}=R_{\mathrm{I}-\mathrm{II}-\mathrm{III}} \frac{S_{\mathrm{p}}}{0.85 \rho_{\mathrm{C}} V_{\mathrm{p}}},
$$

where $S_{\mathrm{p}}\left[\mathrm{m}^{2} / \mathrm{g}\right]$ is the specific surface area of the char, $V_{\mathrm{p}}$ $\left[\mathrm{m}^{3}\right]$ is the char volume, and $\rho_{\mathrm{C}}\left[\mathrm{mol} / \mathrm{m}^{3}\right]$ is the carbon density of the char. Figure 9 shows the Arrhenius plots for the combustion calculated from the results of thermobalance and the fixed-bed reactor. From this figure, it was clear that the initial combustion rates changed continuously in all temperature regions. By using the Eq. (12), we tried to fit the calculated values to the experimental values in the case of Coke 3 and Charcoal 3. The fitting parameters (the activation energy and the frequency factor) have been already calculated in the Section 3.2. Here, we modified the Eq. (9) to the following equation by introducing a new fitting parameter $(c)$,

$$
R_{\mathrm{III}}=c k_{d} C_{\infty}=c \frac{S h}{d_{\mathrm{p}}} D_{\mathrm{g}} C_{\infty}
$$

Using the bulk oxygen concentration at $T_{0}\left(C_{0}=9.33 \mathrm{~mol} / \mathrm{m}^{3}\right)$, the interstitial gas velocity pass through particles at $T_{0}$ $\left(u_{\mathrm{g}, 0}=0.106 \mathrm{~m} / \mathrm{s}\right)$, the density of gas flow at $T_{0}\left(\rho_{\mathrm{g}, 0}=\right.$ $\left.1.73 \times 10^{-5} \mathrm{~kg} / \mathrm{m}^{3}\right)$, and the molecular diffusivity at $T_{0}\left(D_{0}=\right.$ $\left.1.81 \times 10^{-5} \mathrm{~m}^{2} / \mathrm{s}\right)$, the fitting parameter $(c)$ was obtained, $c=$ 0.07 for Coke 3 and $c=0.04$ for Charcoal 3. However, the values of the parameter $(c)$, which is a correction coefficient of the combustion rate in Zone III, were considerably small in both carbon materials. This is considered because the Eq. (9) contains only the influence of the transportation of oxygen molecules through the external gas film around the carbon particle. As shown in Table 1, the ash contents in Coke 3 and Charcoal 3 were 11.6 and $3.6 \mathrm{wt} \%$ respectively, which are not negligible. Accordingly, the gas diffusion through
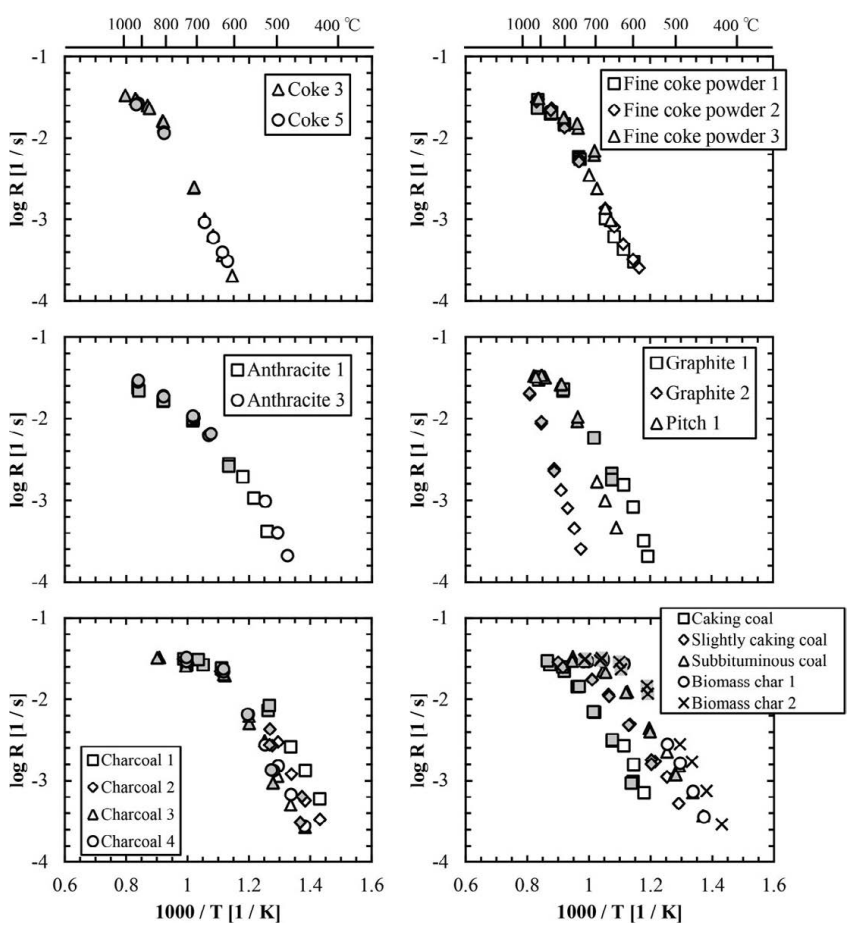

Fig. 9. Arrhenius plots for combustion of carbon materials calculated from the thermogravimetry and fixed-bed reator. 

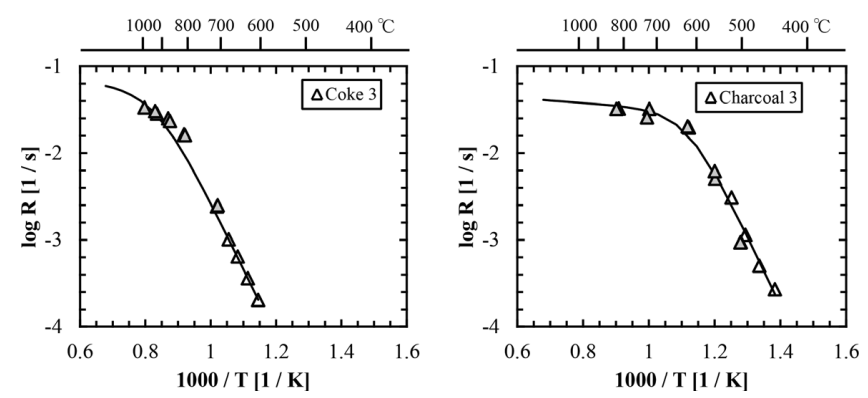

Fig. 10. Comparison of calculated results with experimental data.

the ash layer formed during the combustion of the carbon materials must also be taken into account in the combustion rate analysis. Although many models for gas-solid reaction have been proposed, we should pay attention to an unreacted core model. This model is consisted of the following three stages: (1) the gas diffusion through the external gas film, (2) the gas diffusion through the ash layer, and (3) the chemical reaction on the surface of the unreacted core. The small value of parameter $(c)$ obtained in this study suggests the significant contribution of the stage (2) or stage (3) to the combustion rate of the carbon materials.

Figure 10 shows the results of fitting in the cases of Coke 3 and Charcoal 3. Finally, we can express the overall combustion rate as a function of temperature $(T)$.

In the case of Coke 3,

$$
\begin{gathered}
R_{\mathrm{II}}=9.1 \times 10^{3} \times T^{-0.25} \times \sqrt{\exp \left(-\frac{1.8 \times 10^{4}}{T}\right)} \times\left(\frac{1}{\tanh \xi}-\frac{1}{\xi}\right) \\
\xi=4.2 \times 10^{5} \times T^{-0.75} \times \sqrt{\exp \left(-\frac{1.8 \times 10^{4}}{T}\right)} \\
R_{\mathrm{III}}=3.6 \times 10^{-3} \times T^{0.5} \times\left(2+2.8 \times T^{-0.25}\right) \ldots \ldots \ldots \ldots \ldots \ldots \ldots \ldots \ldots \ldots \ldots \ldots \ldots \ldots \ldots \ldots \ldots \ldots \ldots \ldots \ldots \ldots
\end{gathered}
$$

In the case of Charcoal 3,

$$
\begin{aligned}
& R_{\mathrm{II}}=2.7 \times 10^{5} \times T^{-0.25} \times \sqrt{\exp \left(-\frac{1.9 \times 10^{4}}{T}\right)} \times\left(\frac{1}{\tanh \xi}-\frac{1}{\xi}\right) \\
& \xi=5.0 \times 10^{6} \times T^{-0.75} \times \sqrt{\exp \left(-\frac{1.9 \times 10^{4}}{T}\right)} \\
& R_{\mathrm{III}}=2.1 \times 10^{-3} \times T^{0.5} \times\left(2+2.8 \times T^{-0.25}\right)
\end{aligned}
$$

In the Zones I and II, the combustion rate $\left(R_{\mathrm{II}}\right)$ can be calculated if the activation energy, the frequency factor, and the porosity are obtained. The porosity can only be measured by the method performed in this study, the porosimetry, or other methods. As for the activation energy and the frequency factor, we can obtain by measuring the thermogravimetry directly or estimate using the relationship between the combustion parameters ( $E$ and $A$ ) and the proximate and ultimate analyses shown in Figs. 6 and 7. In the Zone III, the fitting parameter $(c)$ can be expected easily, since the combustion rate hardly differs among the types of the carbon materials. From above results, it was found that we could estimate the overall combustion rate by obtaining the values of the activation energy, the frequency factor, and the porosity.

\section{Conclusions}

The proximate and ultimate analyses, the specific surface areas, the particle densities, and the porosities were measured as the physical and chemical properties of the carbon materials used in this study. Cokes and fine coke powders had a small amount of volatile matter $(<4.1 \mathrm{wt} \%)$ and a large amount of carbon $(>90.4 \mathrm{wt} \%)$ and ash $(>9.4 \mathrm{wt} \%)$. On the contrary, the volatile matter contents in Charcoal 1 , Charcoal 2, Caking coal, Slightly caking coal, Subbituminous coal, Pitch 2, and Biomass char 2 were larger than $24.8 \mathrm{wt} \%$. The proximate and ultimate analyses of the devolatilized carbon materials from the biomass were almost the same as those of the cokes and fine coke powders. The specific surface area and the porosity were different among the types of the carbon materials. The combustion rates were analyzed by using the thermobalance and the fixed bed combustion instrument. In the chemical reaction rate determining step (Zone I), it was seen that the combustion temperature of the cokes and fine cokes powders at the weight conversion $X=0.05-0.20$ was between 600 and $700^{\circ} \mathrm{C}$, which was higher than that of the carbon materials with large amounts of volatile matter. The activation energies for the combustion differed greatly depending on the types of the carbon materials, from $150-190 \mathrm{~kJ} / \mathrm{mol}$ for the cokes and fine coke powders to $70-110 \mathrm{~kJ} / \mathrm{mol}$ for the carbon materials with large amounts of volatile matter. For most of the devolatilized carbon materials, the combustion temperature shifted to the higher temperature side by 50 $200^{\circ} \mathrm{C}$. In the internal diffusion (Zone II) and external diffusion (Zone III) rate determining steps, the differences in the combustion rates became small among the types of the carbon materials and the apparent activation energies for the combustion of the carbon materials became small (10$50 \mathrm{~kJ} / \mathrm{mol}$ ). For obtaining the overall combustion rate, it was found that we need the data of the activation energy, the frequency factor, and the porosity.

\section{REFERENCES}

1) W. Yang, S. Choi, E. S. Choi, D. W. Ri and S. Kim: Combust. Flame, 145 (2006), 447.

2) T. C. Ooi, E. Aries, B. C. R. Ewan, D. Thompson, D. R. Anderson, R. Fisher, T. Fray and D. Tognarelli: Miner. Eng., 21 (2008), 167.

3) R. R. Lovel, K. R. Vining and M. Dell'amico: ISIJ Int., 49 (2009), 195.

4) M. Zandi, M. Martinez-Pacheco and T. A. T. Fray: Miner. Eng., 23 (2010), 1139.

5) S. Y. Lin, Y. Suzuki, H. Hatano and K. Tsuchiya: Chem. Eng. Sci., 55 (2000), 43.

6) W. Klose and M. Wolki: Fuel, 84 (2005), 885.

7) A. Jess and A.-K. Andresen: Fuel, 89 (2010), 1541.

8) S. Kucukbayrak, H. Haykiri-Acma, A. Ersoy-Mericboyu and S. Yaman: Energy Convers. Manage., 42 (2001), 613.

9) H. Haykiri-Acma, A. Ersoy-Mericboyu and S. Kucukbayrak: Energy Convers. Manage., 42 (2001), 11.

10) L. Ma and R. Mitchell: Combust. Flame, 156 (2009), 37.

11) G. Skodras, P. Grammelis, P. Basinas, E. Kakaras and G. Sakellaropoulos: Ind. Eng. Chem. Res., 45 (2006), 3791.

12) J. M. Encinar and J. F. Gonzalez: Fuel Process. Technol., 89 (2008), 678.

13) M. X. Fang, D. K. Shen, Y. X. Li, C. J. Yu, Z. Y. Luo and K. F. Cen: J. Anal. Appl. Pyrolysis, 77 (2006), 22.

14) A. M. C. Janse, H. G. de Jonge, W. Prins and W. P. M. van Swaaij: Ind. Eng. Chem. Res., 37 (1998), 3909.

15) I. Kulaots, I. Aarna, M. Callejo, R. H. Hurt and E. M. Suuberg: Proc. Combust. Inst., Pittsburgh, PA., 29 (2002), 495.

16) I. Kulaots, A. Hsu and E. M. Suuberg: Proc. Combust. Inst., Pittsburgh, PA., 31 (2007), 1897. 